\title{
Three new species of the genus Terminalia L. [Combretaceae]
}

\author{
A. S. Dhabe \\ Department of Botany, Dr. Babasaheb Ambedkar Marathwada University, Aurangabad - 431004, \\ Maharashtra, India \\ E-mail: arvindsdhabe@gmail.com
}

[Received 10.12.2018; Revised 28.12.2018; Accepted 29.12.2018; Published 31.12.2018]

\begin{abstract}
Three new species of the genus Terminalia L. (Combretaceae) are reported from Meghalaya and Gujarat states of India. These are Terminalia kanchii Dhabe (Saputara, Gujarat State), T. maoi Dhabe (Shillong, Meghalaya state) and T. shankarraoi Dhabe (Saputara, Gujarat State).
\end{abstract}

Key words: New species, Terminalia L., India

\section{INTRODUCTION}

The genus Terminalia L. is the second largest pantropical genus of family Combretaceae (subfamily Cobretoideae Engl. \& Diels, tribe Combreteae DC., subtribe Terminaliinae (DC.) Excell \& Stace). It has about 150 species of trees and shrubs (Maurin \& al., 2010; Gere, 2013; Shu, 2007). The name Terminalia L. (1767) is conserved against Bucida L. (1759) (Stace, 2010; Maurin \& al., 2010), Adamaram Adanson (1763) (Wiersma \& al., 2015). [Bucida is also a conserved genus name; it has been conserved over Buceras P. Browne (1756)]. Terminalia is characterized by tree or shrub habit, alternate or sub-opposite leaves crowded at the ends of the branches, presence of glands and/or domatia, inflorescence as spikes or racemes, apetalous flowers, fruits drupes or samara.

For the Indian subcontinent (Bangladesh, India, Myanmar, Nepal, Pakistan \& Sri Lanka) Gangopadhyay and Chakrabarty (1997) reported 18 species of Terminalia (viz., [incl. T. arjuna (Roxb. ex DC.) Wight \& Arn., nom. cons. Rec (as T. cuneata Roth)], $T$. argyrophylla King \& Prain, T. bellerica (Gaertn.) Roxb., T. bialata (Roxb.) Steud., T. calamansanai (Blancho) Rolfe (incl. T. pyrifolia (C. Presl.) Kurz), T. catappa L., T. chebula Retz., T. citrina (Gaertn.) Roxb. (incl. T. manii King). T. elliptica Willd. (as T. tomentosa Wight \& Arn.), T. myriocarpa Van Heurck \& Mull. Arg., T. oliveri Brandis, T. paniculata Roth, T. procera Roxb., T. sharmae M. Gangop. \& Chakrab., T. travancorensis Wight \& Arn., T. triaptera Stapf and T. vermae M. Gangop. \& Chakrab). In contrast for the then British India, Clarke (1878) recorded 12 species, whereas Blatter (1929) reported 20 species. Gangopadhyaya \& Chakrabarty (1997), under the heading "Doubtful/imperfectly known taxa", included T. benghalensis Roxb. ex DC. (as done by C.B. Clarke, 1878), T. foetidissima Griff., and T. gella Dalz. Although they treated T. manii King as conspecies with T. citrina, both are considered as distinct taxa. Furthermore, the taxonomic status of $T$. vermae is considered doubtful by us (cf. The plant list, 2013).

Since 1997, as a part of systematic studies on Indian taxa for Terminalia, field visits were undertaken in different parts of the country. The field trips to Meghalaya and Gujarat states led to the collection of some novel specimens, which could not be assigned to any 
known species of Terminalia. A study of the protologues of T. chebula (Retzius 1779) and T. citrina Roxb. (Roxburgh 1832) and published literature and experts' comments on the identity of the relevant specimens revealed that, those represent three new species of Terminalia. Accordingly, three new Terminalia species names are presented here.

Terminalia kanchii Dhabe, sp. nov.

Similar to Terminalia chebula Retz. but differs in possessing thick ovate elliptic leaves; ovate elliptic drupes, with short stalk tapering towards base, tip beaked; oblong lanceolate nuts.

Medium sized trees, 6 to $9 \mathrm{~m}$ tall; bark rough, greyish-brownish-blackish, splits irregularly. Tender branches green, pubescent, mature branches brownish creamish, glabrous, lenticular. Leaves opposite or sub opposite; lamina thick, ovate, ovate-elliptic or elliptic-oblong, 4.0 $8.0 \times 8.0-18.0 \mathrm{~cm}$, entire, acute or acuminate, base rounded, obtuse, acute or cuneate; lateral veins $6-10$ paired, both surfaces pubescent when young, glabrous at maturity; petioles 1.5 to $2.5 \mathrm{~cm}$ long, 1.0 to $2.0 \mathrm{~mm}$ thick, striated; glands 2 or 1 or absent, situated on petiole below the lamina or at the junction of petiole and lamina, circular to elliptic, green, creamish or yellow, $1-3 \mathrm{~mm}$. Spikes terminal, simple, 3 to $10 \mathrm{~cm}$ long or panicled, 7 to $15 \mathrm{~cm}$ long, axis pubescent, green, $20-35$ flowered. Flowers sessile, bracteate, bracts linear, $1.5-2.0 \mathrm{~mm}$ long, pubescent; all bisexual, actinomorphic, epigynous, $4-6 \mathrm{~mm}$ across. Calyx cup green,

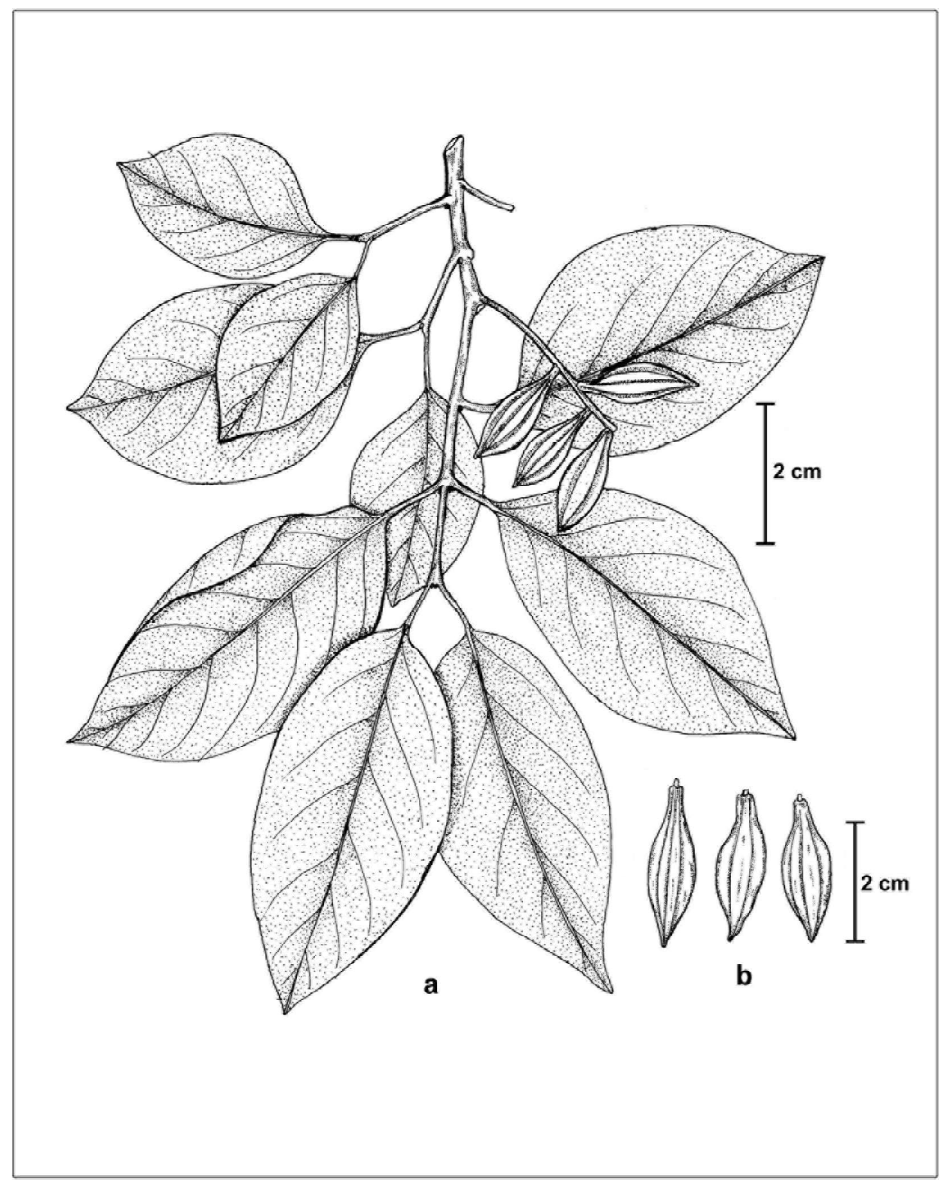

Figure 1. Terminalia kanchii sp. nov. a. Fruiting branch; b. Fruits 
324 Three new species of Terminalia $\mathrm{L}$.
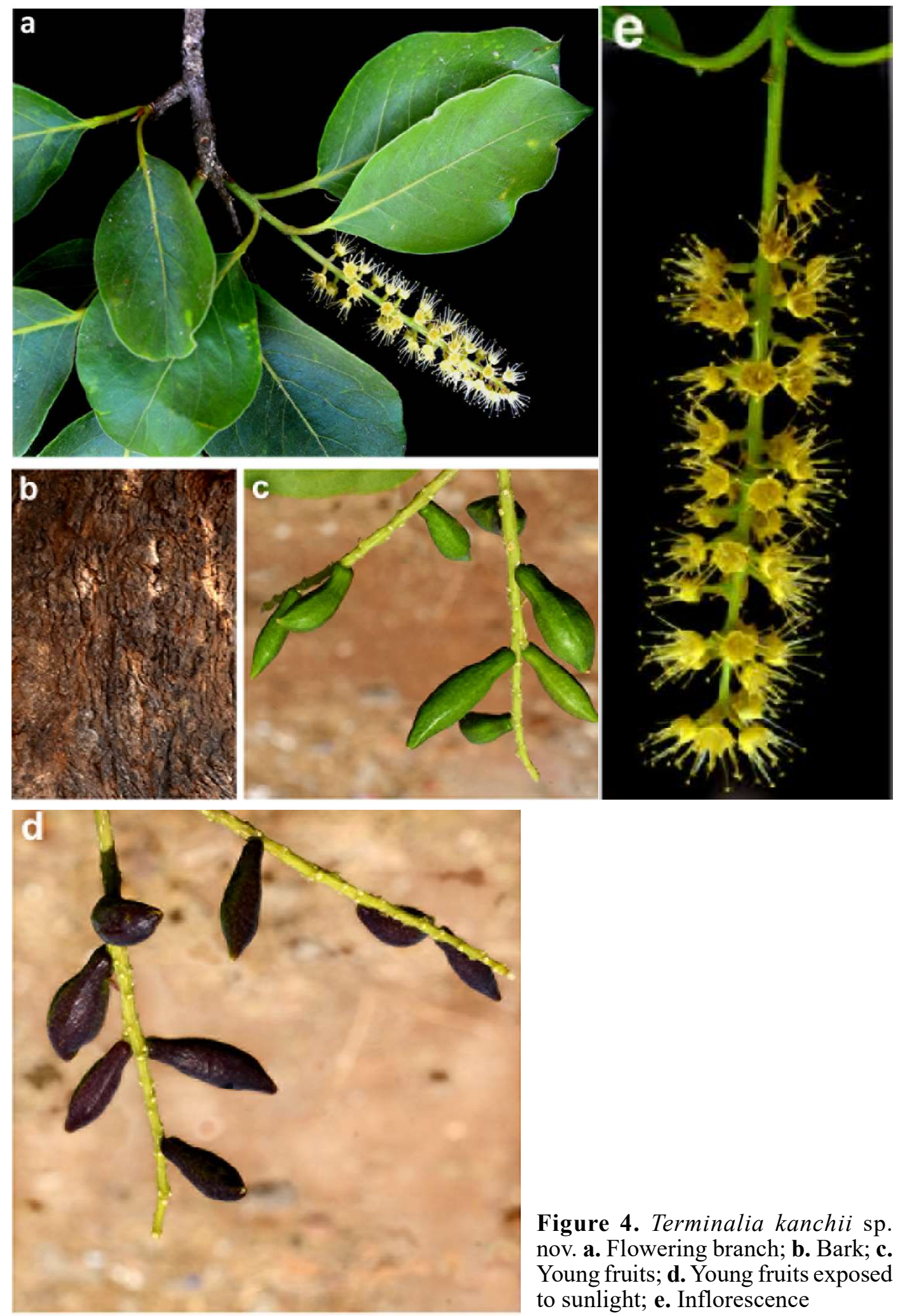

Figure 4. Terminalia kanchii sp. nov. a. Flowering branch; b. Bark; c. Young fruits; d. Young fruits exposed to sunlight; e. Inflorescence 
glabrous outside, silky villous inside, creamish at center, $2-3 \mathrm{~mm}$ long; lobes 5 , broadly triangular, $1.5-2.0 \mathrm{~mm}$ long. Stamens 10; filaments glabrous, creamish yellow; anther lobes dorsifixed, dithecous, ovate, yellow. Ovary $2.0-2.5 \mathrm{~mm}$ long, $1.0-1.5 \mathrm{~mm}$ across, swollen at the middle, slightly tapering at the ends, pubescent, green; style shorter than stamens, glabrous, greenish yellow, stigma pointed. Drupes elliptic oblong with short stalk $(3-7 \mathrm{~mm})$ tapering towards base, tip beaked, $2.5-4.5 \mathrm{~cm}$ long, $1.2-1.7 \mathrm{~cm}$ across, green when young, purple on exposure to sunlight, yellowish brown at maturity. Nuts $1.5-2.2 \mathrm{~cm}$ long, $8-12 \mathrm{~mm}$ across, oblong lanceolate to ovate lanceolate, tapering to both ends, with 5 ridges, surface rough, outline of cross section rounded with 5 obscure angles. Seeds ovate elliptic, 8 - $14 \mathrm{~mm}$ long, 2-3 mm wide, reddish brown, tip blackish.

Phenology: Terminalia kanchii blooms in March - April and fruiting during August December.

Type: INDIA, Gujarat, Saputara, N20 35' 11.5"; E073 45' 44.7'; Alt.: 904 m, dated 20.12.2015, A. S. Dhabe- 007203, (Holotypus: CAL; Isotypus: BAMU); Gujarat, Saputara, dated 05.10.2003, A. S. Dhabe, 002503 (Paratypus: BAMU!).

Distribution: Distributed in Ahwa forest, Gujarat state, India.

Status: Critically endangered.

Etymology: The species is named in honor of Dr. Kanchi N. Gandhi, Senior Nomenclature Registrar, Harvard University Herbaria, Cambridge, MA, USA for his dedicated services in plant nomenclature.

Terminalia maoi Dhabe, sp. nov.

Similar to T. citrina (Gaertn.) Roxb. ex Fleming, but differs with elliptic lanceolate fruits, tapering towards ends; mesocarp hard, dark brownish black; elliptic lanceolate nuts, with sharp 5 wings.

Trees, about $18.5 \mathrm{~m}$ tall, bark smooth, reddish - brownish. Young branches smooth, reddish brown. Leaves sub-opposite; lamina elliptic to elliptic-lanceolate, $3.0-5.0 \times 14.0-$ $18.0 \mathrm{~cm}$, entire, acuminate with a long acumina, base cuneate, tapering; lateral veins $7-10$ paired, both surfaces glabrous at maturity; petiole 1.5 to $3.0 \mathrm{~cm}$ long, 1.5 to $2.0 \mathrm{~mm}$ thick; glands 2 , situated on petiole below the lamina, circular, brown, $1 \mathrm{~mm}$ in diameter. Spikes axillary and terminal, simple, 3 to $6 \mathrm{~cm}$ long, rachis brown, glabrous. Flowers not seen. Drupes elliptic lanceolate, tapering towards ends, $4.0-6.5 \mathrm{~cm}$ long, c $1.5 \mathrm{~cm}$ across, green when young, yellowish brown at maturity. Nuts $3.0-4.0 \mathrm{~cm}$ long, $8-12 \mathrm{~mm}$ across, elliptic lanceolate, tapering towards ends, 5 winged, wings sharp, outline of cross section star shaped. Seeds elliptic oblong, compressed, $17-24 \mathrm{~mm}$ long, $2-3 \mathrm{~mm}$ wide, yellowish brown, tip blackish.

Phenology: Terminalia maoi flowers during November to December and fruiting during February to March.

Type: INDIA, Meghalaya, Shillong, Barapani, N25 40'8517"'; E091 54' 1147”; Alt.: 876.7 m, dated 11.03.2016, A. S. Dhabe, 007264, (Holotypus: CAL; Isotypus: BAMU).

Specimens examined: INDIA, Assam, Goalpara, 11.06.1919, Upendranath Kanjilal - 7565, Accession no. 10570 (ASSAM!); INDIA, Assam, Borengajuli, Bornadi Wildlife Sanctuary, 20.09.2010, C. Deori \& D. K. Roy, 49290, Accession no. 83873 \& 83874 (ASSAM!).

Distribution: Distributed in Udulguri, Baksa and Goalpara districts of Assam state and Ribhoi and East Khasi districts of Meghalaya state. Critically endangered. 


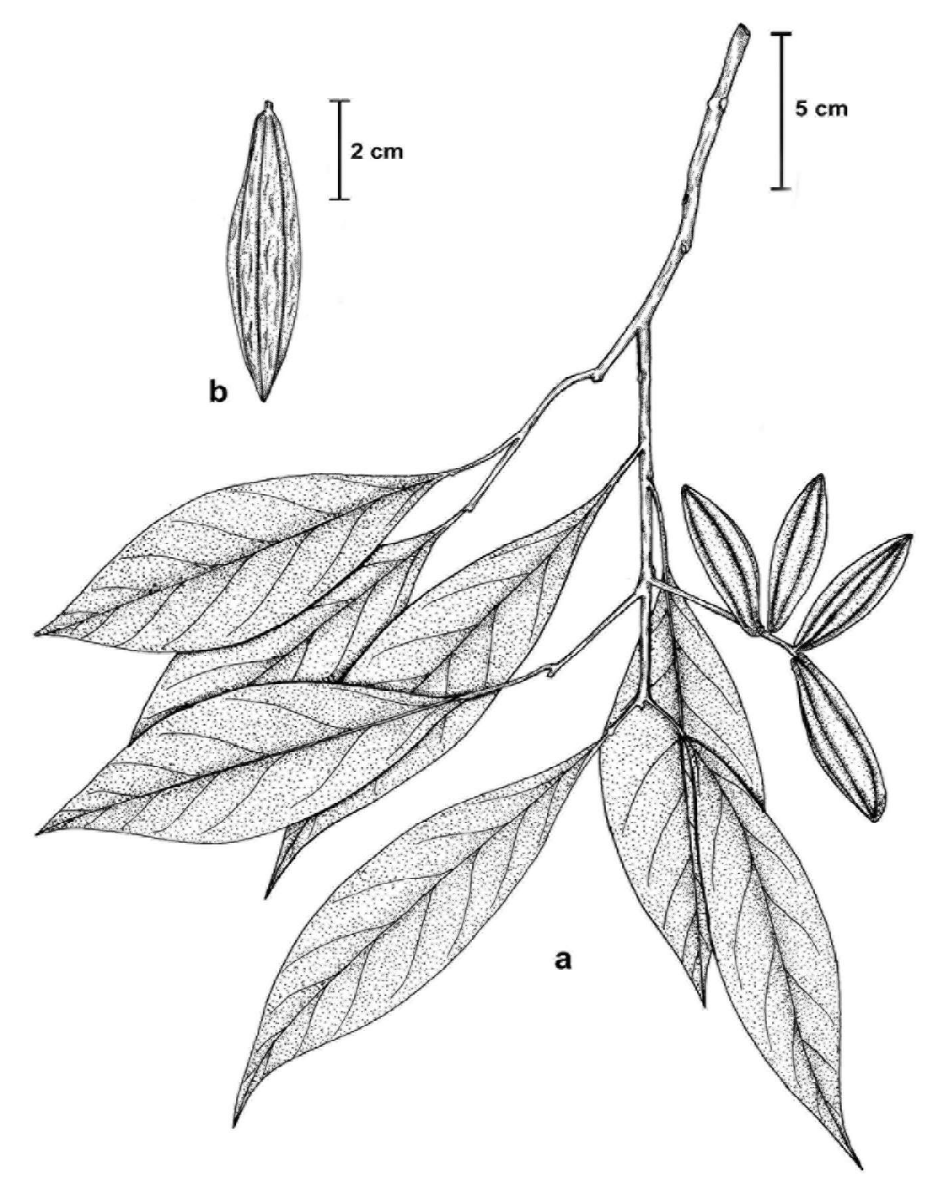

Figure 2. Terminalia maoi sp. nov. a. Fruiting branch; b. Fruit

Etymology: The species is named in honor of Dr. A. A. Mao, Scientist F, Botanical Survey of India (BSI), for his dedicated works in North Eastern India.

Terminalia shankarraoi Dhabe, sp. nov.

Similar to T. chebula Retz. differs in possessing ovate elliptic leaves; elliptic lanceolate fruits with long stalk tapering towards the base; oblong lanceolate nuts and seeds with long stalk tapering towards base.

Trees about $15 \mathrm{~m}$ tall, bark rough, greyish-brownish-blackish, splits irregularly. Tender branches green, silky pubescent; matured yellow brown, rough, lenticular. Leaves alternate or sub opposite;lamina ovate to ovate-elliptic, $4.0-8.0 \times 8.0-20.0 \mathrm{~cm}$, entire, acuminate, base rounded, lateral veins $5-7$ paired, both surfaces silver villous when young, glabrous at maturity; petioles 1.5 to $3.0 \mathrm{~cm}$ long, 2.0 to $2.5 \mathrm{~mm}$ thick, striated; glands 2, situated on petiole below the lamina or at the junction of petiole and lamina, circular to elliptic, green or creamy or yellow with black spot at center in young leaves, brown in matured leaves, 2-3 $\mathrm{mm}$ in diameter. Inflorescence terminal simple spikes simple, terminal, rarely axillary and branched, 3 to $8 \mathrm{~cm}$ long, lateral spikes short; rachis pubescent, green, 14 -35-flowered; bracts linear, $1.5-3.0 \mathrm{~mm}$ long, pubescent. Flowers sessile, all bisexual, actinomorphic, epigynous, $5-7 \mathrm{~mm}$ across. Calyx cup green, glabrous outside, silky villous inside, yellowish 


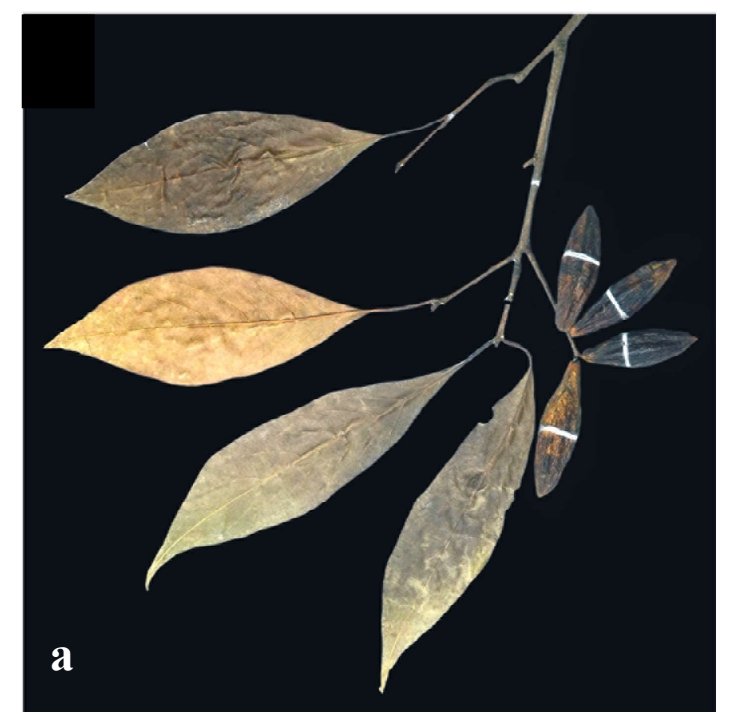

Figure 5. Terminalia maoi sp. nov. a. Fruiting branch
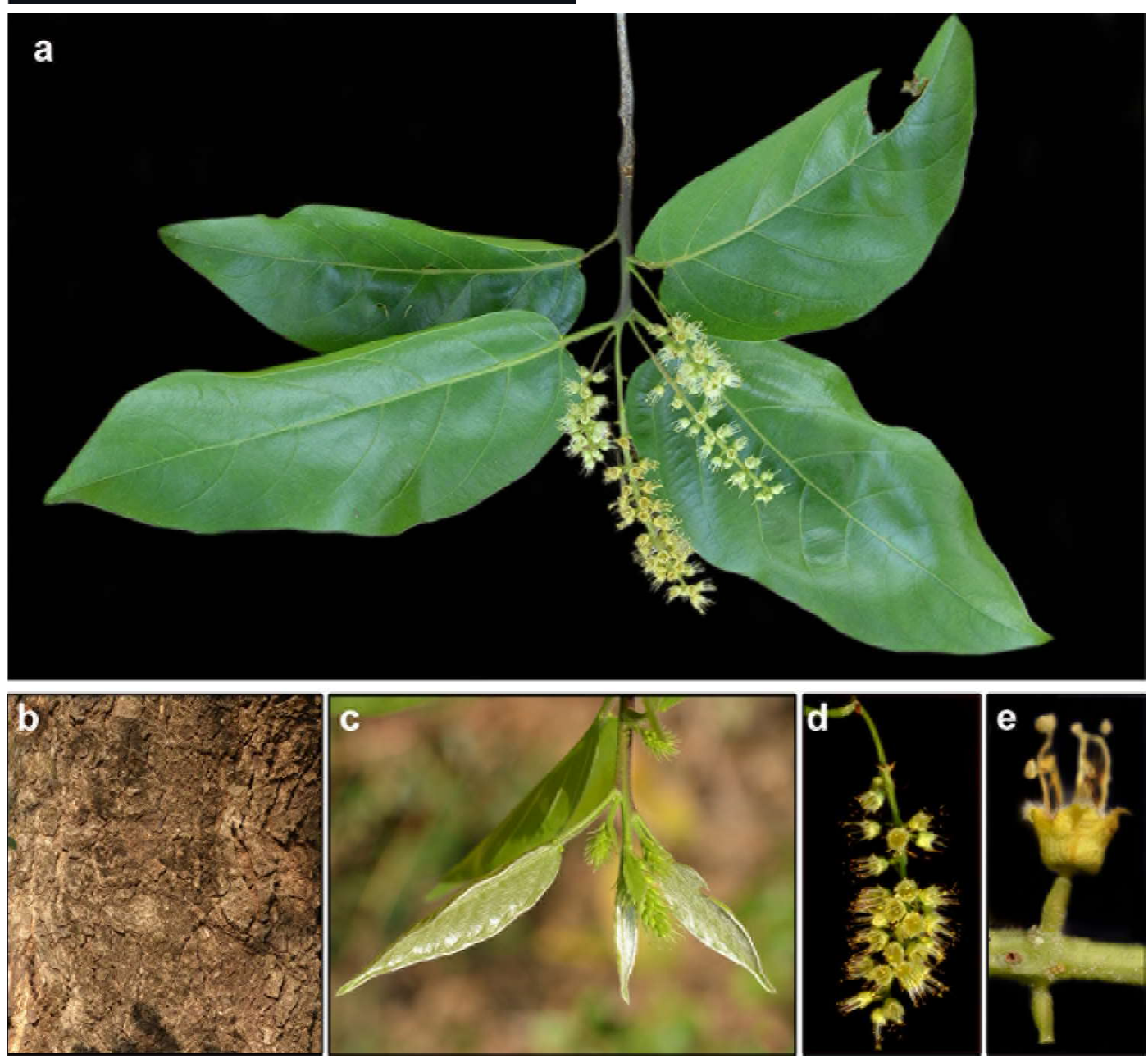

Figure 6. Terminalia shankarraoi sp. nov. a. flowering branch; b. Bark; c. Tender branch; d. Inflorescence; e. Fertilized ovary with rim at tip 


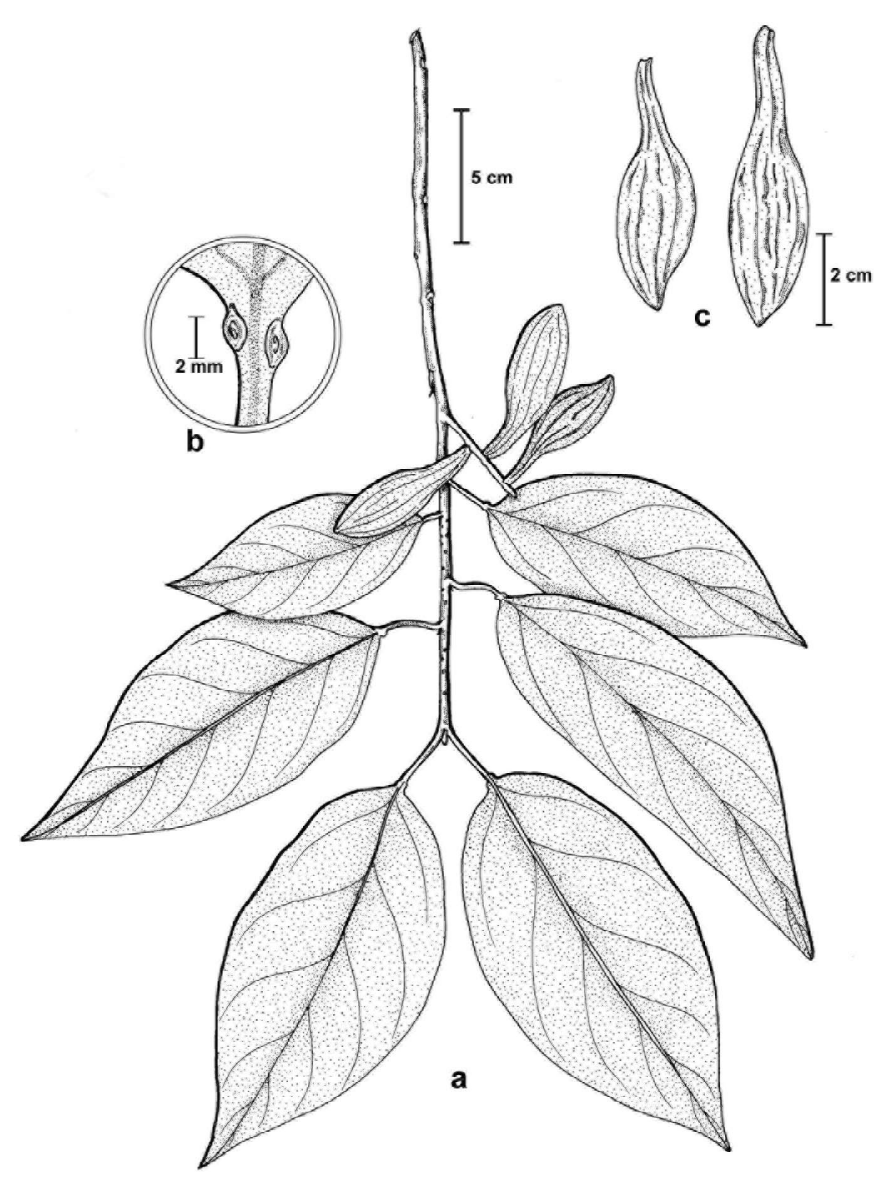

Figure 3. Terminalia shankarraoi sp. nov. a. Fruiting branch; b. Glands; c. Fruits

at center, $2-3 \mathrm{~mm}$ long; lobes 5, 2.5 -3.5 mm long, reflexed outside. Stamens 10; filaments glabrous, cream yellow, 5-8 mm long; anthers dorsifixed, dithecous, ovate, yellow. Style glabrous, cream-coloured, shorter than filaments, stigma pointed. Drupes elliptic lanceolate with long stalk tapering towards base, $4.5-7.0 \mathrm{~cm}$ long, $1.5-2.0 \mathrm{~cm}$ across, green when young, yellowish brown at maturity. Nuts $2.5-3.5 \mathrm{~cm}$ long, $8-14 \mathrm{~mm}$ across, oblong lanceolate, tapering toward the ends, surface rough, outline of cross section rounded with 5 obscure angles. Seeds elliptic-lanceolate, $15-22 \mathrm{~mm}$ long, with long stalk tapering towards base, $2.5-4.0 \mathrm{~mm}$ wide, yellowish brown, tip blackish.

Phenology: Terminalia shankarraoi blooms between March to April and fruiting during August to December.

Type: IINDIA, Gujarat, Saputara, 20 $30^{\prime}$ ' $115^{\prime \prime} \mathrm{N} \& 073^{\circ} 45^{\prime} 4473$ E, Alt. 904 m, dated 20.12.2015, A. S. Dhabe - 007202, (Holotypus: CAL; Isotypus: BAMU); A. S. Dhabe, 006085, Saputara, 29.10.2013 (Paratypus: BAMU)

Specimens examined: V. N. Singh \& Bikarma Singh, Field no. 115994, Accession no. 75967, Nokrek Biosphere Reserve, West Garo Hills, Meghalaya, 13.10.2007 (ASSAM).

Etymology: The species is named in honor of famous traditional Ayurvedic practitioner of Parbhani district, Vd. Shankarrao Govindrao Dhabe who has been using almost all Terminalia 


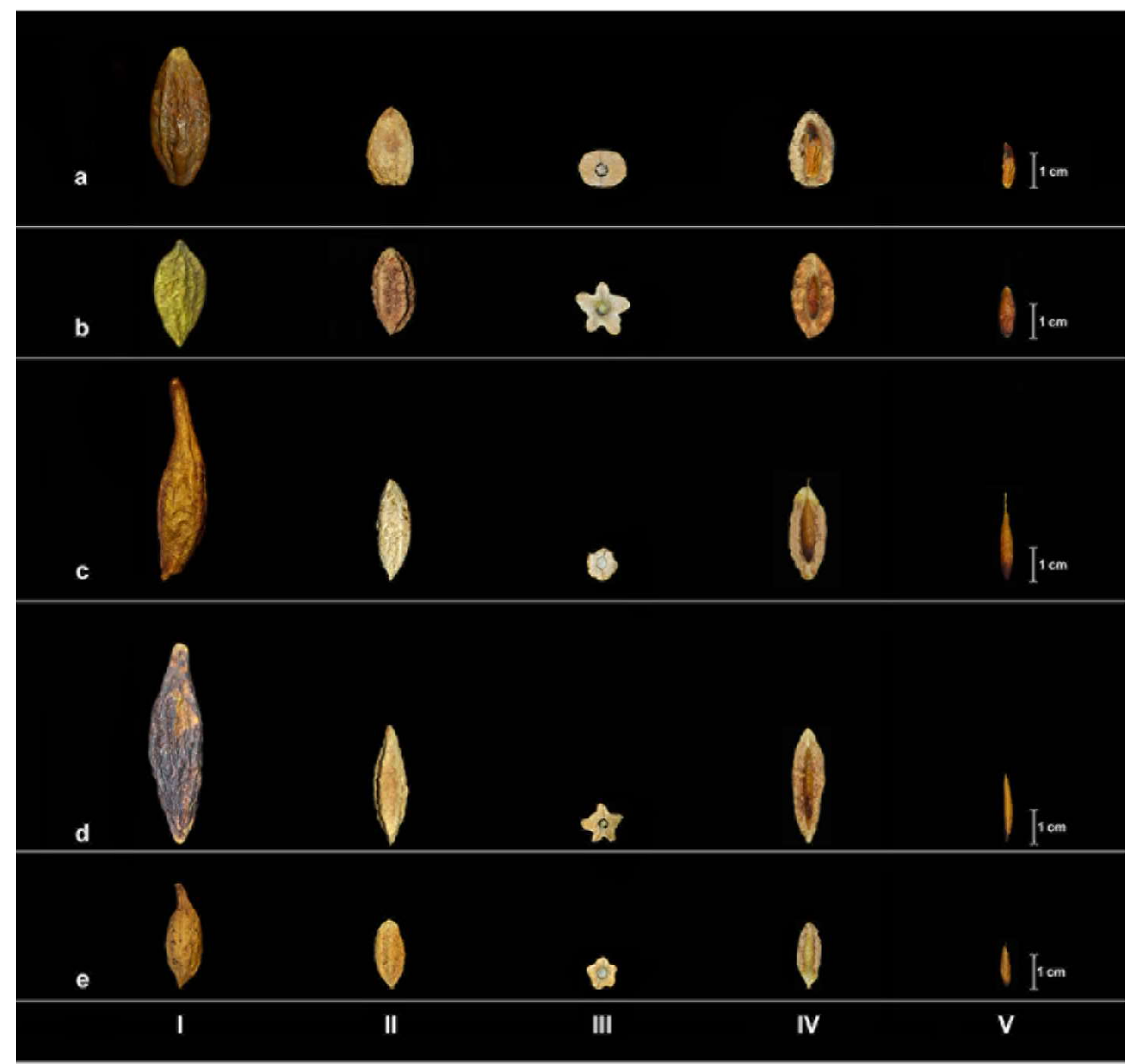

Figure 7. Fruit, nut and seed morphology: a. Terminalia chebula; b. Terminalia citrina; c. Terminalia shankarraoi sp. nov.; d. Terminalia maoi sp. nov.; e. Terminalia kanchii sp. nov.: (i) fruit, (ii) nut, (iii) cross section of nut, (iv) vertically splitted nut, and (v) seed

species in his medicines and because of his association and guidance, author was attracted towards the genus Terminalia.

Distribution: Distributed in Ahwa forest Gujarat and West Garo Hills district of Meghalaya State. Critically endangered.

Key to the identification of Terminalia L. (Combretaceae) species from India

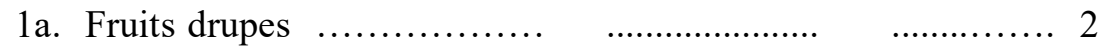

1b. Fruits Samara ............................................. 13

2a. Drupes globbose or ovoid, densely brown tomentose .................. T. bellirica

2b. Drupes otherwise .......................................... 3

3a. Drupes prominently stipitate or stalked ............. $\quad$.......... 4 
3b. Drupes without prominent stipe or stalk

5

4a. Drupes elliptic lanceolate, stipe 10 - $15 \mathrm{~mm}$ long, Seeds elliptic lanceolate, 15-22 mm long, with long stalk tapering towards base

4b. Drupes ovate elliptic, stipe 3-7 mm long, Seeds ovate elliptic, $8-14 \mathrm{~mm}$ long without stalk

T. kanchii

5a. Nuts, 5 winged 6

$5 \mathrm{~b}$. Nuts not winged 7

6a. Drupes elliptic lanceolate; mesocarp hard, dark brownish black; nuts elliptic lanceolate; seeds 17 - $24 \mathrm{~mm}$ long .... T. maoi

6b. Drupes ellipsoidal or oblong lanceolate; mesocarp soft, yellow; nuts elliptic oblong, seeds $12-15 \mathrm{~mm}$ long T. citrina

7a. Drupes warted

T. travancorensis

7b. Drupes not warted 8

8a. Nuts emarginated or broad at apex T. chebula

8b. Nuts not emarginated or broad at apex 9

9a. Mesocarp pulpy, edible, sweet and sour 10

9b. Mesocarp not pulpy, non-edible, astringent 11

10a. Drupes broadly ellipsoid to ovoid, laterally compressed, with stiff narrow ridge, ridges $2-3 \mathrm{~mm}$ broad T. catappa

10b. Drupes ellipsoid to oblong ellipsoid, not compressed, without ridges .... T. procera

11a. Drupes ovate lanceolate; nuts elliptic oblong, 5 ridged; leaves elliptic lanceolate or ovate elliptic T. manii

11b. Drupes globbose-ovoid to ovoid elliptic, nuts ovate oblong, 5 angled; leaves broadly obovate to rounded T. pallida

12a. Samara 2 winged T. bialata

12b. Samara $3-5$ winged ................................. 13

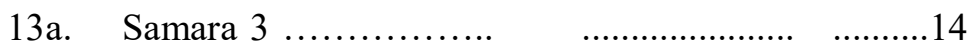

13b. Samara 5 winged ..........................................15

14a. 2 lateral wings well developed, 1 central wing rudimentary... T. myriocarpa

14b. 2 lateral wings rudimentary, 1 central wing well developed... T. paniculata

15a. Striations curved on wings T. arjuna

15b. Striations horizontal on wings T. tomentosa

\section{Acknowledgements}

The author is thankful to the Director, Botanical Survey of India for permitting to consult different Herbaria in India; to Dr. P. G. Diwakar, Pune and Prof. P. K. Sing, Manipur University for constant support; to the Heads of different regional circles of BSI for facilitating; to the authorities of Dr. Babasaheb Ambedkar Marathwada University, Aurangabad for financial support for collection and Herbarium consultation; to Dr. K. N. Gandhi, Harvard University for nomenclature details; to Prof. Oliver Maurin, University of Johannesburg, South Africa for guiding and providing literature; to Prof. Milind Sardesai, Pune for inspiring; to Dr. Ram Gore for illustrations and Mr. B. S. Dhokne for color plates. 


\section{LITERATURE CITED}

Blatter, E. 1929. The Indian species of Terminalia L. J. Indian Bot. Soc. 8: 245 - 262.

Clarke, C. B. 1878. Combretaceae. In: J. D. Hooker (ed.), The Flora of British India. Vol. 2. L. Reeve \& Co., Ltd. Ashford, Kent, London. Pp. 443 - 449.

Gangopadhyay, M. \& Chakrabrty, T. 1997. The Family Combretaceae of Indian Sub- Continent. J. Econ. Taxon. Bot. 21(2): $281-365$

Gere, J. 2013. Combretaceae: Phylogeny, Biogeography and DNA Barcoding. (Unpublished) Ph. D. Thesis submitted to University of Johannesburg, South Africa.

Maurin, O.; Chase, M.W.; Jordaan, M.; Van Der Bank, M. 2010. Phylogenetic relationships of Combretaceae inferred from nuclear and plastid DNA sequence data: implications for generic classification. Bot. J. Linn. Soc. 162: 453 - 476.

Retzius, A.J. 1779. Observations botanicae sex fasciculis comprehensae, Descriptiones Monandrarum in India Orientali Factae. Lipsiae Siegfried Lebrecht Crusium, Quintus: 30 - 31 (www.archive.org/stream/mobot31753003566566\#page/n175/mode/ up/search/Terminalia)

Roxburgh, W. 1832. Flora Indica or Descriptions of Indian Plants, W. Thacker \& Co., Serampore. Vol. 2, 433 - 436. (www.biodiversitylibrary.org/page/6059041\#page/447/ mode/1up)

Shu, Z.H. 2007. Terminalia L. in Flora of China, 13: 310 - 0314.

Stace, C.A. 2010. Combretaceae. Terminalia and Buchenavia with Abdul-Ridha Alwan. Flora Neotropica Monograph 107. BN:978-0-89327-503-7

The Plant List, (2013). Version 1.1 published on the Internet; http://www.theplantlist.org/ (accessed 10 January 2018).

Wiersema, J. H, McNeil, J., Turland, N. J., Barrie, F. R., Buck, W. R., Demoulin, V., Greuter, W., Hawksworth, D. L., Herendin, P. S., Knapp, S., Marhold, K., Prado, J., Prud'homme van Reine, W. F. and Smith, G. F. (eds) 2015. International Code of Nomenclature for Algae, Fungi, and Plants (Melbourne Code): Adopted by the Eighteenth International Botanical Congress, Melbourne, Australia, July 2011; Appendices II VIII. Regnum Vegetabile, 157. Konigstein: Koeltz Scientific Books 